Ilija Mikić

UDK 904:726.8"652"(497.11);

902.2:572.7(497.11)"2005"

Izvorni naučni članak

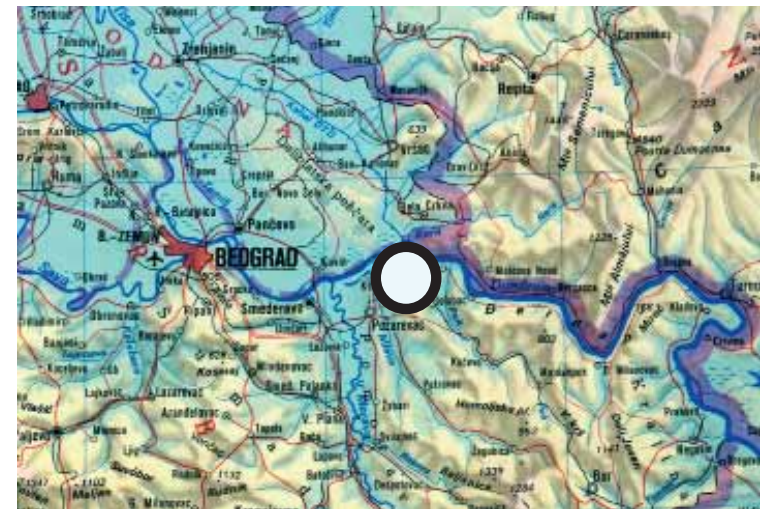

Viminacium, Stari Kostolac, Srbija

LAT 44 44'09" / LONG $21^{\circ} 12^{\prime} 42^{\prime \prime}$

\title{
ANTROPOLOŠKI OSVRT NA PAGANSKU GROBNICU G-2624 ANTIČKOG VIMINACIJUMA
}

\begin{abstract}
APSTRAKT
Paganska grobnica pod brojem G 2624 nađena je na lokalitetu Pećine 1983. godine. Spada među najbolje očuvane oslikane grobnice Viminacijuma. Njen antropološki sadržaj odlično je očuvan zbog čega i zaslužuje posebnu pažnju. Polovinom IV veka u njoj su sahranjene dve individue, $i$ to muškarac star oko 60 godina i devojka stara manje od 20 godina. Smatra se da je baš ova mlada žena predstavljena na zidu grobnice.

Na njenim antropološkim ostacima konstatovana je izražena deformacija praćena erozijom, odnosno osteoporozom, oba femura zbog prebolelog rahitisa u dečijem uzrastu.
\end{abstract}

KLJUČne REČI: ARHEOlOŠKa ISKOPAVANJA, ANTROPOLOŠKa ANALIZA, POLNA PRIPADNOST, INDIVIDUALNA STAROST, STEPEN OČUVANOSTI, PATOLOŠKE PROMENE, RAHITIS.

\section{UVOD}

Tokom arheoloških istraživanja u periodu od sedamdesetih godina XX veka do sada, na Viminacijumu je otkriveno 29 oslikanih grobnica. ${ }^{1}$ Po tome se može zaključiti da njihov broj nije konačan, već da bi sa daljim iskopavanjem trebalo računati sa cifrom nekoliko puta većom od dosadašnje. Najverovatnije da bi taj broj iznosio preko stotinu grobnica. Najveći broj oslikanih grobnica naViminacijumu datuje se u period oko sredine IV veka. $^{2} \mathrm{U}$ to vreme i pagani i hrišćani sahranjivali su se na zajedničkoj nekropoli, što pokazuje da je u urbanim centrima, kakav je bioViminacijum,

1 Korać 2007.

2 Korać 2007. bio moguć spoj paganskog i hrišćanskog.

Ustanovljeno je da su na nekropolama Viminacijuma, na kojima je do danas istraženo oko 14 hiljada grobova, veoma retke sahrane sa tipičnim hrišćanskim obeležjima. Postoji izvestan broj oštećenih ili opljačkanih grobova, kao i onih koji su netaknuti, ali bez grobnih priloga. Te grobove u zoni sahrana iz IV veka nemoguće je pouzdano opredeliti kao paganske ili ranohrišćanske. Pored grobova hrišćana na Viminacijumu koje je 1995. godine publikovala Lj. Zotović, ${ }^{3}$ sahranjuju se i pagani. Iste godine objavljena je i prva ranohrišćanska grobnica sa oslikanim zidovima iz IV ve$\mathrm{ka}^{4}$

3 Zotović 1995.

4 Korać 1995. 
$\mathrm{Na}$ Viminacijumu su oslikane grobnice nalažene u sedam arheoloških kampanja i na tri lokaliteta. ${ }^{5}$

Na lokalitetu Pećine 1983. godine otkrivena je prva grobnica pod brojem $\mathrm{G} 2624$, a zatim su iste godine istražene još tri: G 3130, G 3186 i G 3238.

Godine 1985., na istom lokalitetu nađeno je najviše grobnica. Ukupno je istraženo trinaest: G 3869, G3880, G 3904, G 3941, G 3953, G 3971, G 4006, G 4733, G 4734, G 4736, G 4767, G 4815 i G 4816.

$\mathrm{Na}$ Viminacijumu su 1987. godine otkrivene tri oslikane grobnice: G 5053, G 5337 i G 5350.

Grobnice G 5454 i G 5464 istražene su potonje 1988. godine.

Na lokalitetu Pećine 1990. godine otkrivene su još dve: G 5507 i G 5517.

Na lokalitetu Više Burdelja 1977. godine otkrivene su grobnice G 54, G 55 i G 65.

Na lokalitetu Pirivoj 2003. godine otkrivena je oslikana grobnica G 160 čije su freske, kao i one u grobnicama G 2624 i G 5517 sa Pećina, konzervirane i prezentovane.

Antropološki ostaci iz svih ovih grobnica su izuzetno slabo očuvani. Grobnica G 2624 predstavlja izuzetak, tako da je idealna i za socio-religijsku i za antropološku analizu. Utvrđeno je da je paganska, a nađeni antropološki ostaci direktno se vezuju za mladu žensku osobu naslikanu na čeonoj, zapadnoj strani grobnice.

\section{MATERIJAL I METOD}

Prema statistici očuvanosti skeleta, od 29 oslikanih grobnica Viminacijuma, antropološki ostaci pogodni za obradu nađeni su u ukupno 10 ne računajući G 160 sa lokaliteta Pirivoj koja je otkrivena 2003. godine, a čija je obrada još u toku. To su grobnice na Pećinama označene kao G 2624, G 3130, G 3186, G 3238,G 4768, G 4816, G 5035, G 5313, G 5350 i G 5517. Razlog loše očuvanosti skeleta je u tome što su grobnice uglavnom razrušene, odnosno opljačkane i to najčešće još u antičkom periodu, a ne retko i u savremenom dobu. U navedenim oslikanim grobnicama Viminacijuma, ljudski skeletni ostaci su toliko slabo očuvani da su sa većom ili manjom

5 Korać 2007. verovatnoćom mogli biti utvrđeni samo pol i individualna (biološka) starost sahranjenih osoba.

Iz ostalih grobnica skeletni ostaci nisu mogli biti ni podignuti za antropološku obradu, pošto su nalaženi ili u tragovima ili u dislociranom položaju. U nekima je još tokom arheoloških iskopavanja konstatovan veći broj sahranjenih osoba. ${ }^{6}$

Za vreme arheoloških iskopavanja na lokalitetu Pećine 1983. godine, ustanovljeno je da su u paganskoj grobnici G 2624 bile sahranjene dve osobe: muškarac star oko 60 godina i žena, odnosno devojka stara do 20 godina. Stepen očuvanosti muškog skeleta bio je toliko mali da je mogla biti konstatovana samo izuzetna fragmentovanost kostiju uz nekompletnost skeleta. Međutim, očuvani koštani delovi su po svom robusticitetu na prvom mestu ukazali na muški pol. Rast i razvoj kostiju bio je završen, čak sa znacima dublje starosti (obliteracija lobanjskih šavova), tako da je procenjeno da je osoba imala oko 60 godina u trenutku smrti. Na osnovu raspoloživih ostataka nije bilo moguće izvršiti druge antropološke analize, a nije bilo moguće dobiti ni jedan osteometrijski parametar.

Kad se radi o ženskom skeletu onda je situacija znatno drugačija. Specifična okolnost da je ova grobnica posvećena baš ovoj osobi omogućila je višestruku analizu. Takozvana pilot-skica očuvanosti ovog ženskog skeleta ( $\mathrm{T}$. 1) pokazuje da je nađen njegov manji deo, ali u poređenju sa antropološkim sadržajima ostalih grobnica sa Viminacijuma svakako je najkompletniji. Lobanja je očuvana u fragmentovanom stanju $i$ to samo delom leve parietalno-temporalne zone. Gornji ekstremiteti su, takođe, očuvani u fragmentima. Od većih komada dugih kostiju izdvajaju se različiti delovi oba humerusa, a slična je situacija i sa podlakatnim kostima. Karlična krila (Os coxae) su očuvana u gornjim delovima i to samo desne strane. Najbolje su očuvani femuri koji su i najznačajniji za ovaj antropološki osvrt (T. 1). Od podkolenih kostiju očuvani su različiti delovi tibija. Uz veće fragmente uglavnom dugih kostiju koje je bilo moguće i pouzdano orijentisati (po strani pripadanja skeletu), nađeno je i dosta usitnjenih komada lobanje, kičmenih pršljenova, rebara, šaka i stopala. Međutim, zbog svoje po-

6 Korać 2007. 
roznosti nisu mogli biti ni podignuti iz grobnice.

Treba napomenuti da ni zubi nisu očuvani.

Metodologija antropološke obrade skeletnih ostataka iz paganske grobnice G 2624 kreće se u okvirima standardizovane metodologije utvrđivanja polne pripadnosti i individualne starosti. ${ }^{7}$ To znači da je pol muškog skeleta određen prema elementima za individue kod kojih je završen morfološki rast i razvoj kostiju. Dominiraju naglašeni prečnici dugih kostiju i jako naglašena hvatišta mišića. $\mathrm{S}$ druge strane, kod ženskog skeleta, pol je utvrđen prema elementima karakterističnim za fazu rasta i razvoja, ali u korelaciji sa izraženom vrlo gracilnom građom kako fragmenata dugih kostiju tako $i$ malobrojnih lobanjskih delova.

Individualna starost muškog skeleta je već pomenuta i bila je u trenutku smrti oko 60 godina. Ali, pošto je utvrđena na osnovu samo jednog elementa navedene metodologije, odnosno visokog stepena sraslosti lobanjskih šavova na očuvanim delovima, dobijeni podatak treba shvatiti okvirno.

Individualna starost ženskog skeleta je mogla biti utvrđena opet samo na osnovu jednog elementa navedene i primenjivane metodologije, ali znatno pouzdanijeg, a to je stepen okoštavanja epifiznih okrajaka dugih kostiju. Kako se vidi na manje obolelom femuru (T. 1), epifizna fuga same glave femura još je otvorena i nedostaje. Pošto ona kod osoba ženskog pola srašćuje između 15. i 19. godine života, zaključeno je da je u trenutku smrti ova individua imala manje od 20 godina.

Više oboleli levi femur (T. 2) zahvaćen je izraženom destrukcijom i unutrašnje i spoljne strukture gornjeg dela, a što jasno potvrđuje rentgenski snimak oba femura. Krajnji ishod, odnosno nalaz, je poremećaj u osifikaciji praćen izraženom osteoporozom. Kada se radi o humanom osteološkom materijalu sa arheoloških nalazišta, zaključke je moguće donositi na osnovu što potpunijeg opisa i dokumentovanja određenog defekta, a ne uporednim dijagnozama, pošto antropolog na raspolaganju ima samo jedno tkivo ljudskog organizma. Naravno, nove laboratorijske metode mogu znatno doprineti boljim i novim rezultatima prilikom ovakvog pristupa.

7 Ferembach et al. 1980; Rösing et al 2005.

\section{DISKUSIJA I ZAKLJUČAK}

Na čeonoj, zapadnoj strani grobnice G 2624 nalazi se portret pokojnice, čiji su antropološki ostaci centralna tema ovog osvtra. To je ujedno i centralna freska ove grobnice i dočarava nam osobu kojoj je grobnica namenjena. Predstavljena je ženska osoba koja u trenutku smrti nije imala više od dvadesetak godina.

Za razliku od drugih grobnica, u kojoj su ljudske figure naslikane prilično šematizovano i tipizirano, ova pokojnica nije prikazana ni hijeratično ni konvencionalno.

Lik je individualizovan i može se pretpostaviti da je rađen prema modelu. Portret je inače samo jedna od bitnih odlika sepulkralne paganske ikonografije. Izuzetno je čest na stelama i sarkofazima, a nešto je ređi u slikarstvu grobnica. Njegova osnovna karakteristika je da se u simboličkom značenju oslanja na zamisao apoteoze pokojnika.

Pokojnica je predstavljena frontalno sa pogledom na desnu stranu. Vidi se da se radi o mladoj ženi ili devojci izduženog, ovalnog lica, krupnih kestenjastih očiju, pravilnog nosa, naglašenih senzualnih usana i nežnog i dugog vrata. Za razliku od lica sluge prinosioca, sa naglašenim rumenilom na obrazima, lice i vrat ove pokojnice su izvedeni polutonovima oker i bele boje, bez potenciranja njene očigledne mladosti.

Boja kose pokojnice je kestenjasta. Pada do visine brade, oštro je savijena i zabačena unazad. Preko nje je prebačena tanka mrežica. Poznato je da su udate žene bile ili gologlave ili su pokrivale glavu velom koji je imao različite oblike. Devojke su, pak nosile mrežice, krugove ili čeone trake. ${ }^{8}$ Pokojnica iz grobnice G 2624 prikazana je do pojasa. Odevena je u skupocenu i tešku, indigom obojenu brokatnu i drapiranu stolu. ${ }^{9}$

Predstava nema analogija u funerarnom slikarstvu. Najviše analogija ima u gliptici i mozaičkoj umetnosti. Slikar koji je radio ovaj portret posvetio je posebnu pažnju glavi pokojnice, uključujući i detalj sa mrežicom koji treba da predstavlja njeno devojaštvo.

Paleopatološka analiza femura pokojnice, koji su ujedno i najbolje očuvani delovi njenog skeleta, pokazali su, s jedne strane njenu individu-

8 Sidow 1969.

9 Wilpert 1898; Huston 1920; Wilson 1938; 
alnu starost, a sa druge njeno zdravstveno stanje. Analiza i rentgensko snimanje su obavljeni decembra 2005. godine na Antropološkom institutu Ludvig Maksimilijan Univerziteta u Minhenu, uz konsultovanje odgovarajuće literature. ${ }^{10}$ Pokazalo se da se radi o prebolelom rahitisu koji je zapravo poremećaj u prometu kalcijuma i fosfata u krvi i tkivima. Drugim rečima, radi se o pomanjkanju D vitamina, što u dečijem uzrastu prouzrokuje rahitične promene na skeletu, a kod odraslih osteomalacijum. U ovom slučaju to je mogao biti jako otežan hod, na granici nepokretnosti.

Bez obzira što nemamo na raspolaganju sve duge kosti pokojnice, ili bar veći deo njenog skeleta, dobili smo dovoljno dokaza da zaključimo da je njeno zdravstveno stanje bilo veoma loše i da ne bi mogla podneti eventualnu trudnoću. Zaključujemo da je slikar svakako poznavao njenu ličnost u celini, a mreža za kosu sa njegovog portreta kao znak devojaštva poklapa se sa ovim paleopatološkim nalazom. Ovo je samo još jedan primer interdisciplinarnom pristupu nekom problemu. U ovom slučaju, a što je karakteristično uopšte u novijim istraživanjima Viminacijuma, konfrontirani rezultati arheologije, istorije umetnosti i biofizičke antropologije, ukazali su na jedinstven i zajednički rezultat.

\section{BIBLIOGRAFIJA}

Ferembach et al. 1980.

D. Ferembach, I. Schwidetzky, M. Stloukal, Recommendations for Age and Sex Diagnoses of Skeletons, Journal of Human Evolution 9, London 1980, 517-549.

\section{Korać 1995.}

M. Korać., The Paintings in the Late Classical Tombs in Viminacium, The Age of Tetrarchs, SANU, Belgrade 1995.

\section{Korać 2007.}

M. Korać, Slikarstvo Viminacijuma, Centar za nove tehnologije - Viminacijum, Beograd 2007.

\section{Ortner, Putschar 1985.}

D.J. Ortner, Putschar W.G., Identification of Pathological Conditions in Human Skeletal Remains, Smithsonian Institution Press., Waschington 1985.

\section{Rösing et al. 2005.}

F. W. Rösing, M. Graw, B. Marre, S. Ritz-Timme, M. A. Rothschild, K. Rötzscher, A. Schmeling, I. Schredör und G. Geserick, Empfehlungen für die forensische Geschlehts - und Alterdiagnose am Skellet, Anthrop. Anzeiger 63/2, Stuttgart 2005, 221-232.

\section{Sidow 1969.}

W. von Sidow, Zur Kunstgeschichte des spätantiken Portraits im 4. Jahrhundert n. Chr. dans Antiquities Reiche 3. 8, Bonn 1969.

\section{Stuart 1989.}

P. L. Stuart-Macadam, Nutritional Deficiency Diseases: A Survey of Scurvy, Rickets, and Iron-Deficiency Anemia, in: Reconstruction of Life From the Skeleton, Alan R. Liss, Inc, 201 $-222$.

\section{Wilpert 1898.}

J. S. Wilpert, Die Gewandung der Christen in der ersten Christlichen Jahrhunderten, Köln 1898 .

\section{Wilson 1938.}

L. M. Wilson, The Clothing of the Ancient Romans, London 1938.

\section{Zotović 1995.}

LJ. Zotović, Early Christianity in Viminacium, The Age of Tetrarchs, Belgrade 1995. 


\section{ANTHROPOLOGICAL PERSPECTIVE ON THE PAGAN TOMB G 2624 AT ANCIENT VIMINACIUM}

At ancient Viminacium 29 fresco-painted tombs have been discovered up to this point. Three of them (G 2624, G 5517 and G 160) were conserved and reconstructed and thus included in the Viminacium archaeological tourist presentation. Aside from tombs discovered at the beginning of the 20th century, they certainly number over a hundred. Regarding chronological elements, most of the fresco-painted tombs can be dated to the middle of the 4th century. Since, according to their character, they include both pagan and Christian burials, this confirms that both sects were buried at the common necopolis at Viminacium.

The pagan tomb G 2624 was discovered in 1983 at the site of Pećine. It is one of the best preserved tombs from ancient Viminacium. It contained the skeletal remains of two persons: a male of about 60 years of age and those of a girl, certainly younger than 20 , who was depicted on the western wall and to whom the tomb was dedicated. On her anthropological remains (see Pl. 1) pathological changes were noticed, including deformations related to bone necrosis and osteoporosis, especially of the left femur attributed to healed rachitis (see Pl. 2).

Paleopathological analysis of the femur of the deceased, which represented the best preserved part of her skeleton, showed her individual age, but on the other side also her health condition. The analysis and $\mathrm{X}$-ray examination were undertaken in December 2005 at the Anthropological Institute of the Ludwig Maximilian University in Munich. Literature research was also included. The diagnosis was healed rachitis, representing abnormal calcium and phosphate formation in blood and tissues. In other words, one is dealing with the lack of vitamin D which, at a young age, results in rachitic changes of the skeleton and at adult age in osteomalation. In this case it could have resulted in extremely impaired walking ability, almost at the edge of immobility.

Disregarding the fact that we do not have all the other long bones of the deceased at our disposal, or even most of her skeleton, there was sufficient evidence to infer that her health condition would not permit marriage. We can conclude that the painter certainly knew the whole of her personality. The hair net on her portrait, as a sign of girlhood, supports this finding. This paper is an example of an interdisciplinary approach to a paleopathological problem. In this case, typical of modern research at Viminacium, archaeological results were compared to the history of art and to biophysical anthropology, providing a unique and common result.

Translated by Milica Tapavički-Ilić 


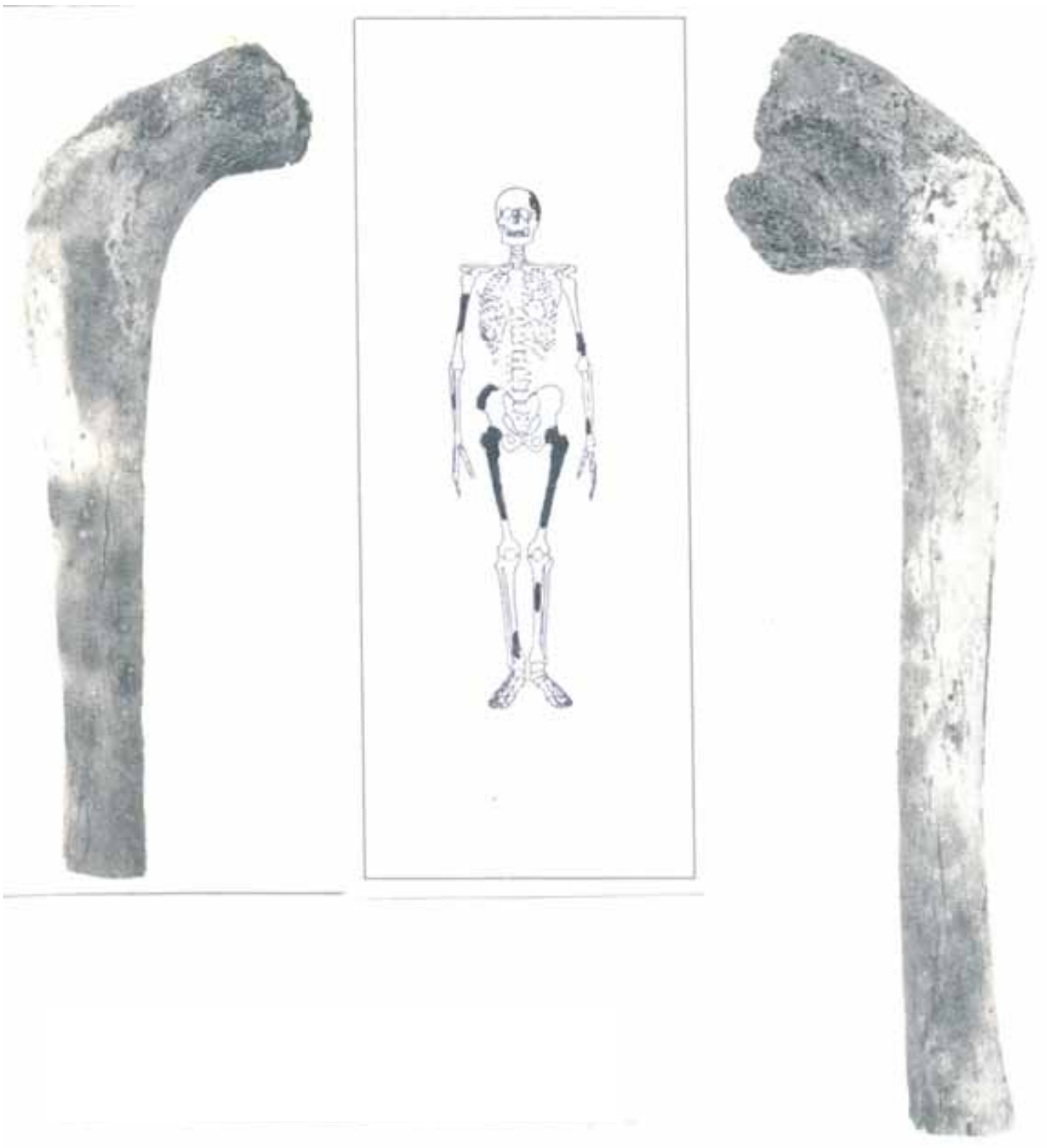

Tabla 1. Skica očuvanosti ženskog skeleta i fotografije obolelih femura 


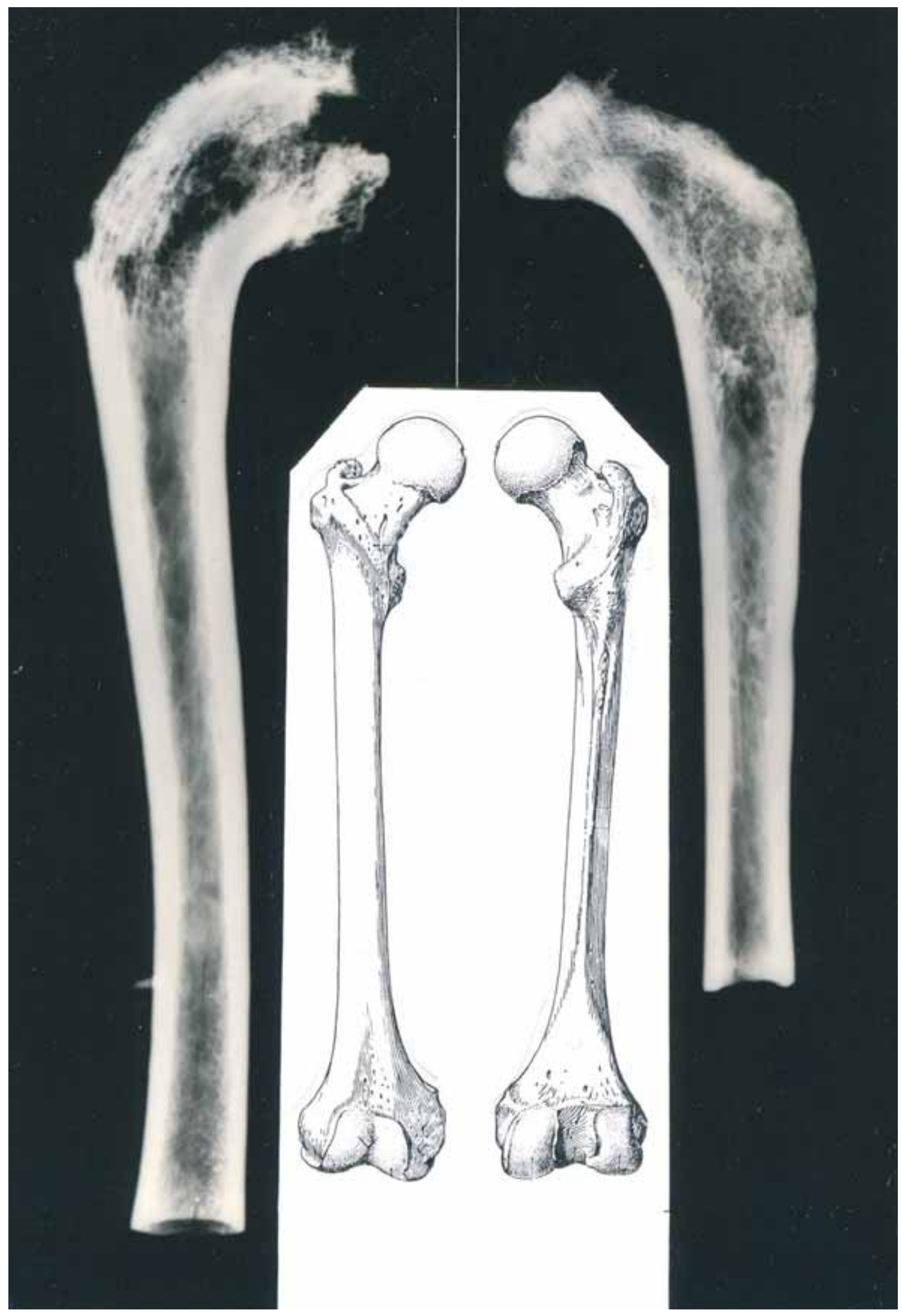

Tabla 2. Rentgenski snimci obolelih femura u poređenju sa normalnim femurom 